\title{
Comparative enzymology of 11ß-hydroxysteroid dehydrogenase type 1 from six species
}

\author{
Spyridon Arampatzis*, Bert Kadereit*, Daniela Schuster ${ }^{1}$, Zoltan Balazs, \\ Roberto A S Schweizer, Felix J Frey, Thierry Langer ${ }^{1}$ and Alex Odermatt
}

Division of Nephrology and Hypertension, Department of Clinical Research, University of Berne, Freiburgstrasse 15, 3010 Berne, Switzerland

${ }^{1}$ Institute of Pharmacy, University of Innsbruck, Innrain 52, A-6020 Innsbruck, Austria

(Requests for offprints should be addressed to A Odermatt; Email: alex.odermatt@dkf.unibe.ch)

*(S Arampatzis and B Kadereit contributed equally to the present study)

\begin{abstract}
$11 \beta$-Hydroxysteroid dehydrogenase type 1 (11 $\beta$-HSD1), catalyzing the intracellular activation of cortisone to cortisol, is currently considered a promising target to treat patients with metabolic syndrome; hence, there is considerable interest in the development of selective inhibitors. For preclinical tests of such inhibitors, the characteristics of $11 \beta$-HSD1 from the commonly used species have to be known. Therefore, we determined differences in substrate affinity and inhibitor effects for $11 \beta$-HSD1 from six species. The differences in catalytic activities with cortisone and 11-dehydrocorticosterone were rather modest. Human, hamster and guinea-pig 11 $\beta$-HSD1 displayed the highest catalytic efficiency in the oxoreduction of cortisone, while mouse and rat showed intermediate and dog the lowest activity. Murine 11 $\beta$-HSD1 most efficiently reduced 11-dehydrocorticosterone, while the enzyme from dog showed lower activity than those from the other species. 7-Ketocholesterol (7KC) was stereospecifically converted to $7 \beta$-hydroxycholesterol by recombinant $11 \beta$-HSD1 from all species analyzed except hamster, which showed a slight preference for the formation of $7 \alpha$-hydroxycholesterol. Importantly, guinea-pig and canine $11 \beta$-HSD1 displayed very low 7-oxoreductase activities. Furthermore, we demonstrate significant species-specific variability in the potency of various $11 \beta$-HSD1 inhibitors, including endogenous compounds, natural chemicals and pharmaceutical compounds. The results suggest significant differences in the three-dimensional organization of the hydrophobic substrate-binding pocket of $11 \beta-H S D 1$, and they emphasize that species-specific variability must be considered in the interpretation of results obtained from different animal experiments. The assessment of such differences, by cell-based test systems, may help to choose the appropriate animal for safety and efficacy studies of novel potential drug candidates.
\end{abstract}

Journal of Molecular Endocrinology (2005) 35, 89-101

\section{Introduction}

Glucocorticoids act through binding to the glucocorticoid receptor (GR), thereby transactivating or transrepressing a multitude of genes involved in various physiologic processes, including modulation of stress and inflammatory responses, maturation and differentiation of cells, and regulation of bone, carbohydrate and lipid metabolism (Barnes 1998, De Bosscher et al. 2003). Glucocorticoids exist in an inactive (cortisone in humans, 11-dehydrocorticosterone in rodents) and an active form (cortisol in humans, corticosterone in rodents), whereby the prereceptor enzyme $11 \beta$ hydroxysteroid dehydrogenase type 1 (11 $\beta$-HSD 1$)$ plays a key role in the control of the local amplification of glucocorticoid action by catalyzing the oxoreduction of inactive 11-keto- to active $11 \beta$-hydroxyglucocorticoids (Stewart \& Krozowski 1999, Sandeep \& Walker 2001). $11 \beta-H S D 1$ is expressed in most organs, with high expression in liver and white adipose tissue. A second enzyme, $11 \beta$-HSD2, is expressed mainly in mineralocorticoid target tissues and catalyzes the inactivation of $11 \beta$-hydroxyglucocorticoids to 11-ketoglucocorticoids, thereby protecting the mineralocorticoid receptor (MR) from inappropriate activation by glucocorticoids (Stewart \& Krozowski 1999).

An increased 11 $\beta$-HSD1 oxoreductase activity results in elevated intracellular activation of GR, causing upregulation of key enzymes for gluconeogenesis. Excessive glucocorticoid action antagonizes the metabolic actions of insulin, causing insulin and leptin resistance, and leading to the development of visceral obesity, type 2 diabetes and the metabolic syndrome (Sandeep \& Walker 2001). The consequences of

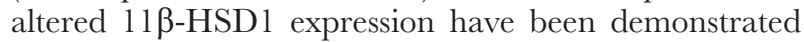
recently in transgenic mice. Hepatic overexpression of $11 \beta$-HSD 1 caused mild insulin resistance without changes in fat depot mass (Paterson et al. 2004). These 
animals exhibit fatty liver and dyslipidemia and are hypertensive with increased liver angiotensinogen expression. Transgenic mice overexpressing $11 \beta$-HSD1 in adipose tissue develop visceral obesity, have elevated adipose corticosterone concentrations and are susceptible to insulin-resistant diabetes, hyperlipidemia and high arterial blood pressure due to increased sensitivity to dietary salt and increased plasma levels of angiotensinogen, angiotensin II and aldosterone (Masuzaki et al. 2001, 2003). In contrast, mice with targeted disruption of $11 \beta$-HSD1 show, upon starvation, attenuated activation of key hepatic gluconeogenic enzymes and are resistant to hyperglycemia provoked by obesity or stress (Kotelevtsev et al. 1997, Morton et al. 2004). Moreover, in humans, 11 -HSD1 expression in subcutaneous adipose tissue is increased in acquired obesity and positively correlates to accumulation of subcutaneous and intra-abdominal fat, body-mass index, percentage of body fat and waist circumference, as well as fasting glucose, insulin levels and insulin resistance (PaulmyerLacroix et al. 2002, Rask et al. 2002, Lindsay et al. 2003, Kannisto et al. 2004, Valsamakis et al. 2004).

Therefore, 11ß-HSD1 is currently considered a promising therapeutic target for the treatment of patients with metabolic and endocrine disorders (Masuzaki \& Flier 2003, Chrousos 2004). Indeed, it was shown recently that the administration of a selective $11 \beta$-HSD1 inhibitor reduces blood glucose levels and increases insulin sensitivity in diabetic mice (Barf et al. 2002, Alberts et al. 2003). Furthermore, inhibition of $11 \beta-$ HSDl improved cognitive function in healthy elderly men and in type 2 diabetics (Sandeep et al. 2004) and lowered intraocular pressure in patients with ocular hypertension (Rauz et al. 2003). These findings induced a vigorous search for selective $11 \beta$-HSD1 inhibitors.

The effects of novel compounds are generally investigated in obese and diabetic mice and in other small laboratory animals. Since rodent physiology is different from human, larger animals such as dogs are commonly used in drug development for safety and efficacy assessment. Despite significant differences between human and animal glucocorticoid metabolism and the importance of $11 \beta-\mathrm{HSD} 1$, relatively little is known about the species-specific differences in substrate and inhibitor specificity of $11 \beta$-HSD1. Recently, studies from our laboratory revealed a novel function of $11 \beta$-HSD1 in the metabolism of 7-ketocholesterol $(7 \mathrm{KC})$, which may play a role in the development of atherosclerosis and dyslipidemia (Schweizer et al. 2004). While human and rat $11 \beta$-HSD1 catalyzed the stereospecific oxoreduction of $7 \mathrm{KG}$ to $7 \beta$ hydroxycholesterol, the hamster enzyme was not stereospecific and led to the formation of both $7 \alpha$ - and $7 \beta$-hydroxycholesterol, indicating significant speciesspecific differences in $11 \beta$-HSD 1 activity. In the present study, we cloned and characterized canine $11 \beta$-HSD1; compared the specificity of $11 \beta$-HSD 1 from six species for the substrates cortisone, 11-dehydrocorticosterone and $7 \mathrm{KC}$; and determined the species-specific effects of various inhibitors.

\section{Materials and methods}

\section{Materials}

Cell culture media were purchased from Invitrogen (Carlsbad, CA, USA); [1,2,6,7- $\left.{ }^{3} \mathrm{H}\right]$-cortisone from American Radiolabeled Chemicals (St Louis, MO, USA); cortisone, 11-dehydrocorticosterone and $7 \mathrm{KG}$ from Steraloids (Wilton, NH, USA); and reagents for derivatization from Pierce (Rockford, IL, USA).

Radiolabeled 11-dehydrocorticosterone was produced from $\left[1,2,6,7-{ }^{3} \mathrm{H}\right]$-corticosterone, as described previously (Schweizer et al. 2004). Chenodeoxycholic acid (CDCA), abietic acid, flavanone, 2'-hydroxyflavanone, glycyrrhetinic acid (GA) and carbenoxolone (GBX) were from Fluka AG (Buchs, Switzerland), and were of the highest grade available. $5 \mathrm{H}-1,2,4-$ Triazolo(4,3-a)azepine, 6,7,8,9-tetrahydro-3-tricyclo $(3 \cdot 3 \cdot 1 \cdot 13 \cdot 7)$ dec-1-yl-32709342-5 (T0504) was purchased from Enamine (Kiev, Ukraine).

\section{Construction of 11 1 -HSD1 expression plasmids}

The cloning of human (Tannin et al. 1991), rat (Agarwal et al. 1989), mouse (Oppermann et al. 1995, Rajan et al. 1995) and guinea-pig 11ß-HSD1 cDNA (Pu \& Yang 2000) has been reported earlier, as has the construction of untagged and FLAG epitope-tagged human, rat and hamster 11ß-HSD1 (Odermatt et al. 1999, Schweizer et al. 2004). Mouse and guinea-pig 11ß-HSD1 were amplified by PCR using specific oligonucleotide primers based on available sequences from GenBank. Canine $11 \beta$-HSD 1 was cloned from the liver of a poodle. Total RNA was isolated with the Trizol reagent, according to the instructions of the manufacturer (Invitrogen), followed by reverse transcription and synthesis of double-stranded cDNA. 11 $\beta$-HSD1 was amplified by PCR using Taq-polymerase:Pfu-polymerase (10:1). A degenerated oligonucleotide at the 5 '-end (5'-TATG GATCCAGCAAGNTCCCTGTYDGATG-3'), based on comparison with the sequences upstream of the initiation codon of $11 \beta$-HSD1 from other species, and oligo- $\mathrm{dT}_{20}$, containing an XbaI site, at the $3^{\prime}$-end were used for initial PCR amplification. A single DNA product was obtained, cleaved with BamHI and XbaI and cloned into Bluescript vector. The sequences of 8 of 10 clones analyzed were identical. Two products contained errors introduced by the polymerase and were discarded. For the construction of $11 \beta$-HSD 1 expression plasmids, all sequences were modified by PGR amplification, using an oligonucleotide at the $5^{\prime}$-end, 
containing a BamHI endonuclease restriction site followed by a Kozak consensus sequence, the ATG initiation codon and 18-20 nucleotides of speciesspecific $11 \beta$-HSD1 sequence, and an oligonucleotide at the 3 '-end containing specific-specific sequence, 24 nucleotides encoding the FLAG epitope, the stop codon and an $\mathrm{XbaI}$ endonuclease restriction site. The sequence encoding the FLAG epitope was omitted in the primer used for the construction of the untagged expression plasmid. The PCR product was cleaved with BamHI and $\mathrm{XbaI}$ and cloned into pcDNA3. 1 expression vector (Invitrogen). All expression constructs were verified by sequencing.

\section{Cell culture, protein expression and Western blotting}

HEK-293 cells were cultured in Dulbecco's Modified Eagle's Medium (DMEM) supplemented with 10\% fetal calf serum (FCS), 50 units $/ \mathrm{ml}$ penicillin, $50 \mathrm{mg} / \mathrm{ml}$ streptomycin and $2 \mathrm{mM}$ glutamine, followed by

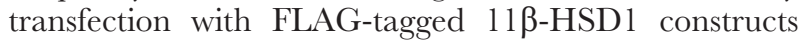
(10 $\mu \mathrm{g}$ plasmid DNA per $10 \mathrm{~cm}$ culture dish) using the $\mathrm{Ca}^{2+}$-phosphate precipitation method. Cells were washed three times $24 \mathrm{~h}$ after transfection with steroidfree (doubly charcoal-treated) medium and grown for another $24 \mathrm{~h}$. Cells were then detached with PBS, centrifuged for $3 \mathrm{~min}$ at $150 \mathrm{~g}$ and resuspended in the appropriate volume of TS2 buffer $(100 \mathrm{mM} \mathrm{NaCl}$, $1 \mathrm{mM}$ EGTA, $1 \mathrm{mM}$ EDTA, $1 \mathrm{mM} \mathrm{MgCl}_{2}, 250 \mathrm{mM}$ sucrose, $20 \mathrm{mM}$ Tris-HCl, pH 7•4). Cells were lyzed by sonication followed by immediate analysis of enzyme activities and protein expression. Protein concentrations were determined by the Bradford assay. The expression level in different transfection experiments was determined semiquantitatively by immunoblotting. An amount of $30 \mu \mathrm{g}$ total proteins was separated on $12 \%$ SDSpolyacrylamide gels and transferred electrophoretically to polyvinyl difluorid (PVDF) membranes (Amersham), followed by visualization with mouse monoclonal anti-FLAG antibody M2 (Invitrogen), horseradish peroxidase (HRP)conjugated goat antimouse immunoglobulin $(\mathrm{Ig}) \mathrm{G}$ and the enhanced chemiluminescence (ECL) Western detection system from Pierce (Rockford, IL, USA). Upon staining for $11 \beta$-HSD 1 , the membranes were stripped, and the expression of $\beta$-actin was determined. Data were analyzed by scanning densitometry with NIH Image $1 \cdot 60 \mathrm{~b} 7$ software.

\section{Determination of 11 $\beta$-HSD1-dependent oxoreduction of cortisone and 11-dehydrocorticosterone}

The 11 $\beta$-HSD1-dependent 11-oxoreduction of cortisone and 11-dehydrocorticosterone was determined by measuring the conversion of cortisone to cortisol, or 11-dehydrocorticosterone to corticosterone in cell lysates in the presence of radiolabeled tracer, as described recently (Atanasov et al. 2004, Schweizer et al. 2004). Briefly, lysates were incubated in TS2 buffer containing $500 \mu \mathrm{M}$ NADPH, $30 \mathrm{nCi}\left[1,2,6,7-{ }^{3} \mathrm{H}\right]$-labeled tracer and various concentrations of unlabeled substrate ranging from $20 \mathrm{nM}$ to $2 \mu \mathrm{M}$. 11 1 -HSD2-dependent oxidation of cortisol was measured similarly with radiolabeled cortisol and $\mathrm{NAD}^{+}$, as described earlier (Atanasov et al. 2003). Samples in a final volume of $20 \mu \mathrm{l}$ were incubated at $37^{\circ} \mathrm{C}$ for $10-15 \mathrm{~min}$, reactions were stopped by adding $2 \mathrm{mM}$ unlabeled glucocorticoids dissolved in methanol, and steroids were separated by thin-layer chromatography (TLC) and analyzed by scintillation counting. In all reactions, the conversion of cortisone was kept below $30 \%$. For calculation of $\mathrm{V}_{\text {max }}$, the expression level of the FLAG-tagged enzyme was compared with the expression signal from $\beta$-actin as an internal control. Apparent $K_{\mathrm{m}}$ and $V_{\max }$ values of the $11 \beta$-HSD1-dependent oxoreduction of cortisone or 11-dehydrocorticosterone were calculated by nonlinear regression, assuming Michaelis-Menten kinetics. Comparable results were obtained by linear transformations (Eadie-Hofstee and Lineweaver-Burk equations). Results are expressed as mean \pm S.D. and consist of three independent measurements.

\section{Analysis of 11ß-HSD1 inhibitors}

Measurements of 11-oxoreductase activity at $37^{\circ} \mathrm{C}$ for 10 min were started by simultaneously adding $10 \mu \mathrm{l}$ cell lysate and $12 \mu \mathrm{l}$ TS2 buffer containing NADPH (400 $\mu \mathrm{M}$ final concentration), $30 \mathrm{nCi}\left[1,2,6,7-{ }^{3} \mathrm{H}\right]-$ cortisone, unlabeled cortisone $(200 \mathrm{nM}$ final concentration) and the appropriate concentration of the inhibitory compound to be tested. Stock solutions of the compounds in methanol or in DMSO were diluted in TS2 buffer to yield the appropriate concentrations, whereby the concentration of methanol or DMSO in the reactions was below $0 \cdot 1 \%$. Control reactions with or without $0 \cdot 1 \%$ of the solvent showed the same activity. Reactions were performed with $200 \mathrm{nM}$ radiolabeled cortisone for $10 \mathrm{~min}$ at $37^{\circ} \mathrm{C}$ followed by termination by adding $2 \mathrm{mM}$ of unlabeled steroids in methanol and determination of the conversion of cortisone to cortisol as described above. The oxoreduction of 11dehydrocorticosterone was measured similarly, using 11-dehydrocorticosterone and corticosterone respectively. All inhibitors analyzed in the present study yielded typical sigmoid dose-response curves, indicating competition at a single substrate binding site.

To measure $\mathrm{IC}_{50}$ values in intact cells, cells were detached $24 \mathrm{~h}$ after transfection, and 30000-40000 cells per well of a 96-well plate were incubated in standard DMEM for another $16 \mathrm{~h}$. The conversion of cortisone to cortisol was then determined upon incubation in serum- and steroid-free medium for $2-4 \mathrm{~h}$ at $37^{\circ} \mathrm{C}$ in a total volume of $50 \mu \mathrm{l}$ medium cotaining 
$200 \mathrm{nM}$ radiolabeled cortisone and the corresponding concentration of inhibitor in the absence of exogenous cofactor. The amount of solvent did not exceed $0 \cdot 1 \%$. Reactions were stopped by adding $25 \mu \mathrm{l}$ methanol containing $2 \mathrm{mM}$ unlabeled steroid, followed by separation of steroids by TLG.

$\mathrm{IC}_{50}$ values were calculated with the Data Analysis Toolbox (Elsevier MDL, San Leandro, CA, USA), assuming first-order rate kinetics. $K_{\mathrm{i}}$ values were calculated from $\mathrm{IC}_{50}$ values by the equation of Cheng and Prusoff (1973). Data represent mean \pm S.D. from at least four independent transfections.

\section{Determination of 11ß-HSD1-dependent oxoreduction of $7 \mathrm{KC}$}

The 7 -oxoreductase activity of $11 \beta$-HSD 1 was determined as described recently (Schweizer et al. 2004). Briefly, freshly prepared lysates expressing $11 \beta$-HSD 1 of the corresponding species were suspended in TG1 buffer $(100 \mathrm{mM} \mathrm{NaCl}, 1 \mathrm{mM}$ EGTA, $1 \mathrm{mM}$ EDTA, $1 \mathrm{mM}$ $\mathrm{MgCl}_{2}, 20 \%$ glycerol, $20 \mathrm{mM}$ Tris-HCl, $\mathrm{pH} 7 \cdot 4$ ) and the reactions carried out in a final reaction volume of $1 \mathrm{ml}$ in the presence of $400 \mu \mathrm{M} \mathrm{NADPH}$ and $800 \mathrm{nM}$ $7 \mathrm{KC}$ for $30 \mathrm{~min}$ at $37^{\circ} \mathrm{C}$. Reactions were stopped by adding $7 \mathrm{ml}$ dichloromethane followed by derivatization and analysis by gas chromatography-mass spectrometry (GC-MS). Data represent mean \pm S.D. from three independent transfections.

\section{Molecular modeling}

Structure-based pharmacophore models for $11 \beta$-HSD 1 inhibitors were derived from the recently published $\mathrm{x}$-ray crystal structures 1XU7 (resolution $0 \cdot 18 \mathrm{~nm}$ ), 1XU9 (resolution $0.16 \mathrm{~nm}$ ), and 2 BEL (resolution $0.21 \mathrm{~nm}$ ) from the PDB (Berman et al. 2000). An additional model consisting only of the features common to $1 \mathrm{XU} 7,1 \mathrm{XU} 9$, and 2 BEL - probably the most important features for $11 \beta$-HSD 1 inhibition - was created automatically by LigandScout (software available from Inte:ligand $\mathrm{GmbH}$, Maria Enzersdorf, Austria, (www.inteligand.com) (Wolber \& Langer 2005). The investigated inhibitors were fitted into a manually constructed pharmacophore model derived from 1XU9 and the common feature model employing the BestFit module of the software package Catalyst (Accelrys Inc., San Diego, GA, USA, Catalyst Version 4.9., www.accelrys.com).

\section{Results}

\section{Cloning of 11 $\beta$-HSD1 from dog and guinea pig and comparison with sequences from other species}

In addition to the previously characterized hamster, rat and human 11ß-HSD1 enzymes (Schweizer et al. 2004), we have now cloned $11 \beta$-HSD 1 from mouse and guinea pig with oligonucleotide primers based on sequences available from GenBank (Oppermann et al. 1995, Rajan et al. 1995). The murine sequence was identical to that present in GenBank. We found three nucleotide differences for guinea-pig 11ß-HSD1: $\mathrm{T}$ for $\mathrm{C}$ at position 64 (initiation codon set as position 1), resulting in $\mathrm{Ser}^{22}$ for Pro; $\mathrm{T}$ for $\mathrm{C}$ at position 308, resulting in $\mathrm{Val}^{103}$ for Ala; and $\mathrm{C}$ for $\mathrm{T}$ at position 564, not affecting the amino-acid sequence. Residue $\mathrm{Ser}^{22}$, which follows the Tyr motif in the transmembrane span, is conserved throughout all known 11ß-HSD1 sequences (Fig. 1). Substitution of Ser by Pro would be critical because of disturbance of the membrane helix. We have previously shown that mutations in the Tyr motif cause partial loss of enzymatic activity, probably due to disturbed folding of the protein (Odermatt et al. 1999). $\mathrm{Val}^{103}$ is also conserved in all known $11 \beta$-HSD1 sequences, except in mouse, which has the closely related hydrophobic residue Ile. The presence of a small residue such as Ala at this position is less likely. In addition to small rodents, dogs are widely used in safety and efficacy studies in the development of pharmaceutical compounds. Therefore, we cloned canine $11 \beta$-HSDl. A sequence comparison revealed $82 \%$ identity and $90 \%$ similarity of human $11 \beta$-HSD 1 with that from $\operatorname{dog}$ and $74-79 \%$ identity and $85-89 \%$ similarity with those from hamster, guinea pig, mouse and rat, indicating that dog $11 \beta-\mathrm{HSD} 1$ is only slightly closer to the human enzyme than the corresponding rodent sequences. As shown in Fig. 1, the sequences of $11 \beta$-HSD 1 from various species are highly conserved with the exception of five variable regions. The first variable region contains a potential glycosylation site in seven out of the 15 known sequences. The second variable region precedes the catalytic center of the enzyme with the highly conserved Tyr residue, and the third variable region follows downstream of the catalytic center. The highest sequence variability exists in the C-terminus with a variable region after the residues involved in dimerization and with the region of highest sequence variability at the very C-terminal end.

\section{Expression of 11ß-HSD1 from six species}

The recombinant enzymes from six species were expressed at comparable levels in HEK-293 cells (Fig. 2), indicated by the similar intensities of the signals for $11 \beta$-HSD 1 and $\beta$-actin on each blot. As shown in Fig. 2, human and canine $11 \beta$-HSD 1 have the highest molecular mass $(\sim 35 \mathrm{kDa})$, followed by rat, mouse and hamster $11 \beta$-HSD $1 \quad(\sim 33 \mathrm{kDa})$ and guinea pig $(\sim 32 \mathrm{kDa})$. Inspection of the sequences indicated that the differences in size may be due to distinct glycosylation. Prediction of potential glycosylation sites, using the NetNGlyc 1.0 server of the center for biologic sequence analysis at the Technical University of Denmark (www.cbs.dtu.dk/ services/), suggests that human and canine $11 \beta-\mathrm{HSD} 1$ 

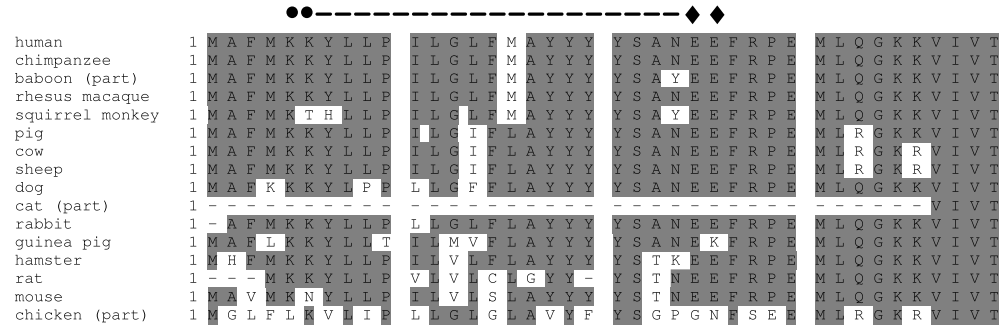

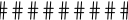


Figure 1 Alignment of the known amino-acid sequences of 11 $\beta$-HSD1 from various species. Identical residues are shaded and the regions of high-sequence variability indicated with a line (regions I-V). Potential glycosylation sites are indicated by an asterisk, the $\mathrm{N}$-terminal transmembrane helix flanked by charged residues determining the orientation of $11 \beta$-HSD1 is indicated by circles (positive) and diamonds (negative), the catalytic Tyr and Lys residues are indicated by (+) and the conserved glycine motif of the Rossmann fold in the cofactor-binding region is indicated by (\#). Accession numbers of the $11 \beta$-HSD1 sequences are as follows: human NM_005525, chimpanzee AY410503, rhesus monkey CO726805, rat NM_017080, mouse NM_008288, hamster, AY519498, guinea pig AY535424, dog AY728264, squirrel monkey S63400, pig NM_214248, cow AF548027, sheep NM_001009395, rabbit Q7 M314, chicken BG710883.

are glycosylated at $\mathrm{Asn}^{123}, \mathrm{Asn}^{162}$ and $\mathrm{Asn}^{207}$. As a control, human 11ß-HSDl was transcribed and translated in vitro, using rabbit reticulocyte lysate and dog pancreas microsomes. Unglycosylated enzyme (band at $\sim 29 \mathrm{kDa}$ ) and enzyme glycosylated at one, two or all three sites was detected (Fig. 2). The band observed upon expression of human 11 $\beta$-HSD 1 in HEK-293 cells corresponds to the fully glycosylated product. Asn ${ }^{123}$ is 


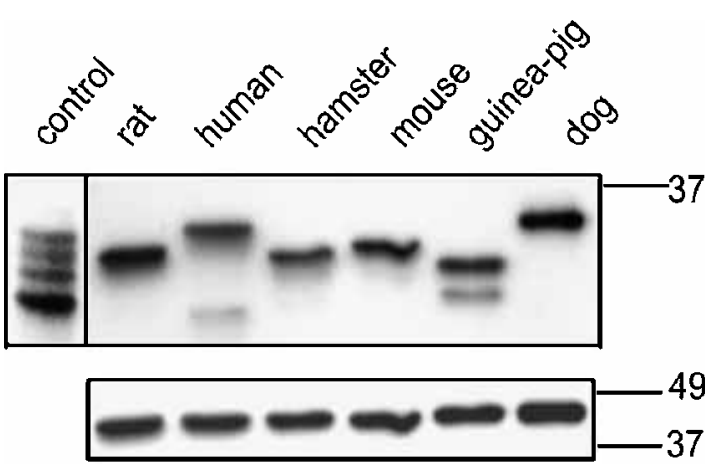

Figure 2 Expression of FLAG-tagged 11 $\beta$-HSD1 from various species. FLAG-tagged $11 \beta$-HSD1 constructs from various species were expressed in HEK-293 cells. An amount of $30 \mu \mathrm{g}$ total protein was separated by $12 \%$ SDS-PAGE, transferred to PVDF membranes and detected with monoclonal anti-FLAG antibody, as described in Materials and methods. After stripping of the membrane, the expression of $\beta$-actin was detected as an internal control for the amount of protein. The upper panel shows the expression of $11 \beta$-HSD1 from various species. The first lane shows $11 \beta$-HSD1 protein after in vitro transcription and translation in the rabbit reticulocyte system, using dog pancreas microsomes as a control. Expression of $\beta$-actin in the same samples is depicted in the bottom panel. The size of protein standard $(\mathrm{kDa})$ is indicated.

located in a region with high sequence variability and is replaced by Gln in rat and mouse and by Tyr in hamster and guinea pig. Asn ${ }^{162}$ is conserved in all $11 \beta$-HSD 1 sequences except guinea-pig (Gln), sheep (Ser) and the partial chicken sequence, and $\mathrm{Asn}^{207}$ is present in all known $11 \beta$-HSD1 sequences (Fig. 1).

\section{Variability in substrate specificity}

To identify species-specific substrate variability in $11 \beta$-HSD1, we compared the 11-oxoreduction of cortisone and 11-dehydrocorticosterone by $11 \beta$-HSD 1 from human, dog, mouse, rat, hamster and guinea pig. As shown in Table 1, there were no significant differences in kinetic parameters of human, hamster and guinea-pig $11 \beta-H S D 1$ with the substrate cortisone. Compared with the human enzyme, a reduced $V_{\max }$ was measured for murine $11 \beta$-HSDl and a decreased substrate affinity for rat $11 \beta$-HSD 1 , resulting for both enzymes in a $50 \%$ lower catalytic efficiency $\left(V_{\max } / K_{\mathrm{m}}\right)$. Despite the closest sequence similarity to human $11 \beta$ HSDl, the canine enzyme showed both lower substrate affinity and $V_{\max }$, resulting in fivefold lower catalytic efficiency. As with cortisone, human, hamster and guineapig $11 \beta$-HSD1 showed comparable catalytic activities for the oxoreduction of 11-dehydrocorticosterone. The rat enzyme displayed lower affinity for 11dehydrocorticosterone but higher $V_{\max }$, while the dog enzyme had both lower affinity and $V_{\max }$, resembling the pattern obtained with cortisone. Unlike with cortisone, mouse $11 \beta$-HSD 1 more efficiently catalyzed the oxoreduction of 11-dehydrocorticosterone compared with the human enzyme. Recently, we demonstrated a novel function for $11 \beta$-HSD 1 by catalyzing the 7 -oxoreduction of $7 \mathrm{KC}$ (Schweizer et al. 2004). Here, we confirm the finding that human and rat $11 \beta$-HSD 1 stereospecifically reduce $7 \mathrm{KC}$ to $7 \beta$-hydroxycholesterol, whereas the 7 -oxoreductase activity of the hamster enzyme results in formation of both $7 \alpha$ - and $7 \beta$-hydroxycholesterol (Fig. 3). We extend the previous findings by further showing that mouse, dog and guinea-pig $11 \beta$-HsD 1 also stereospecifically lead to the formation of $7 \beta$-hydroxycholesterol, whereby, the guinea-pig and dog enzymes have very low 7-oxoreductase activities.

\section{Species-specific effects of 11ß-HSD1 inhibitors measured in cell lysates}

The significant species-specific variability in the catalytic efficiency of $11 \beta$-HSD1 for its substrates led us to analyze the inhibitory potency of various compounds, including endogenous inhibitors, natural compounds and pharmaceutical chemicals (Fig. 4). The best-known inhibitors of $11 \beta$-HSD enzymes are glycyrrhetinic acid

Table 1 Kinetic parameters of $11 \beta-H S D 1$ from various species. FLAG-tagged $11 \beta$-HSD1 cDNAs from six species were each expressed in HEK-293 cells. Cells were then incubated in steroid-free medium for $24 \mathrm{~h}$, lysates were prepared and the conversion of radiolabeled cortisone to cortisol or 11-dehydrocorticosterone to corticosterone was measured immediately as described in Materials and methods. Data were analyzed by nonlinear regression and represent mean \pm S.D. from three independent experiments.

Oxoreduction of cortisone

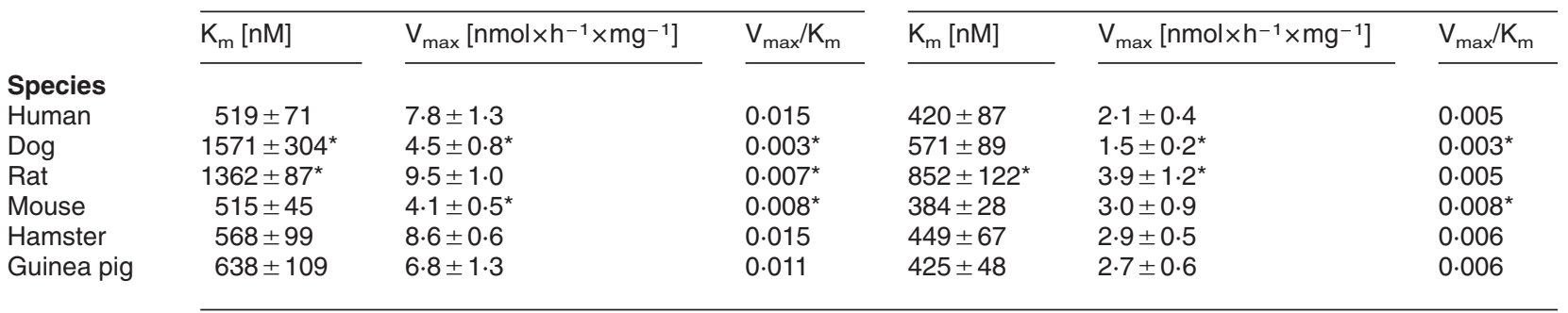

${ }^{*} \mathrm{p}<0.05$ compared with human $11 \beta-H S D 1$. 


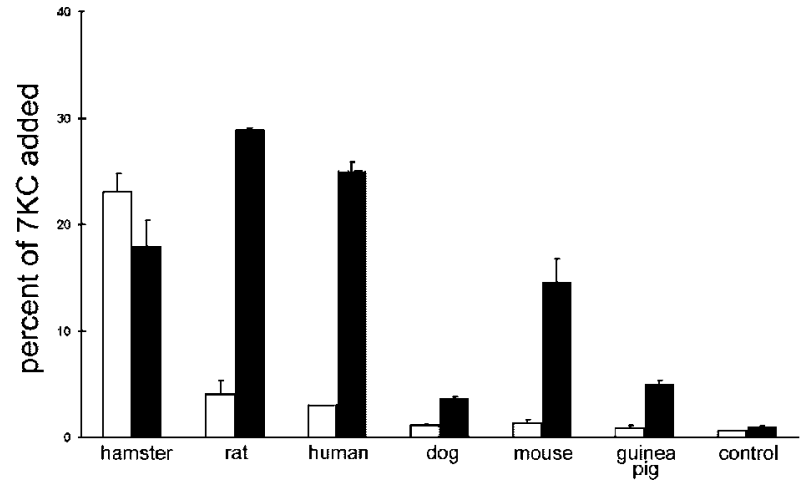

Figure 3 Metabolism of 7-ketocholesterol (7KC) by recombinant $11 \beta-H S D 1$ in cell lysates. Enzymatic activities of recombinant human, dog, rat, mouse, hamster and guinea-pig $11 \beta$-HSD1 were determined in freshly prepared HEK-293 cell lysates upon incubation with $800 \mathrm{nM} 7 \mathrm{KC}$ for $30 \mathrm{~min}$ at $37^{\circ} \mathrm{C}$, as described in Materials and methods. Background activity is shown in untransfected HEK-293 cell lysates (control); $7 \alpha$-hydroxycholesterol, white bars; $7 \beta$-hydroxycholesterol, black bars. Results are expressed as a percentage of initially supplied 7KC.

(GA) and its synthetic analog carbenoxolone (CBX). Analysis of human $11 \beta$-HSD1 and $11 \beta$-HSD2 revealed that both enzymes are efficiently inhibited by GA and CBX, whereby GA preferentially inhibited the latter enzyme (Table 2). A species comparison revealed that GA most potently inhibited the oxoreduction of cortisone by mouse and $\operatorname{dog} 11 \beta$-HSD 1 with two- to threefold lower $K_{\mathrm{i}}$ than $11 \beta$-HSD1 from human, rat, hamster and guinea pig. The closely related synthetic compound CBX inhibited mouse, rat and human $11 \beta$-HSD 1 with $K_{\mathrm{i}}$ values very close to those obtained with GA. In contrast, CBX was about three times less effective than GA in inhibiting dog, hamster and guinea-pig 11ß-HSD1. CBX inhibited murine $11 \beta$ HSD 1 nine to ten times better than that of hamster and guinea pig. Abietic acid, a naturally occurring diterpenoid, widely used in cosmetics, that inhibits both $11 \beta$-HSD1 and 11 $\beta$-HSD2 (Schweizer et al. 2003), most potently inhibited rat $11 \beta$-HSD1; showed similar effects on human, dog, mouse and hamster enzymes; but was a very weak inhibitor of guinea-pig $11 \beta$-HSD 1 . In contrast, flavanone and 2'-hydroxyflavanone, present in yellow and red fruits and vegetables, both selectively inhibited $11 \beta$-HSD1, but not $11 \beta$-HSD2, and showed efficient inhibition of the hamster and guinea-pig enzymes, with only weak effects on $11 \beta$-HSD 1 from human, dog, rat or mouse. In addition, we compared the inhibitory effect of the bile acid CDCA on the $11 \beta$-HSD1-dependent oxoreduction of cortisone from the six species and observed dramatic differences (Table 2). CDCA potently inhibited rat and canine $11 \beta$-HSD1 with $K_{\mathrm{i}}$ values of 550 and $770 \mathrm{nM}$, had intermediate effects on murine and human $11 \beta-H S D 1$ with fivefold higher $K_{\mathrm{i}}$ values, and showed very weak inhibitory effects on hamster and guinea-pig 11 -HSD1 with 50-fold higher $K_{\mathrm{i}}$ values.

Currently, there is considerable effort in the pharmaceutical industry to develop highly potent and

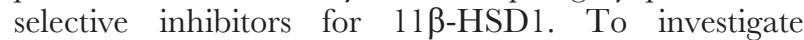
whether such compounds have distinct effects on $11 \beta$-HSD 1 from various species, we have chosen compound T0504 from a compound library of Enamine Ltd, which is described by Merck in patent WO 03/065983. This compound displayed approximately 100 -fold selectivity for the inhibition of human $11 \beta$-HSD1 $\left(K_{\mathrm{i}} 15 \mathrm{nM}\right)$ compared with human $11 \beta-$ HSD2 $\left(K_{\mathrm{i}} 2 \mu \mathrm{M}\right)$. Although 11 $\beta$-HSD1 from all species tested were potently inhibited, analysis of the six species revealed significant differences. Hamster $11 \beta$-HSD 1 was most potently inhibited with a $K_{\mathrm{i}}$ of $6 \mathrm{nM}$, followed by human $11 \beta$-HSD 1 with a $K_{\mathrm{i}}$ of $15 \mathrm{nM}$. The inhibitory effect on rat $11 \beta$-HSD 1 was seven times lower and for dog, mouse and guinea-pig 11 -HSD1 over 10 times

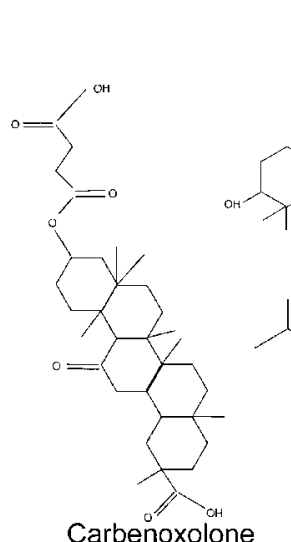

Figure $411 \beta$-HSD1 inhibitors used in the present study.
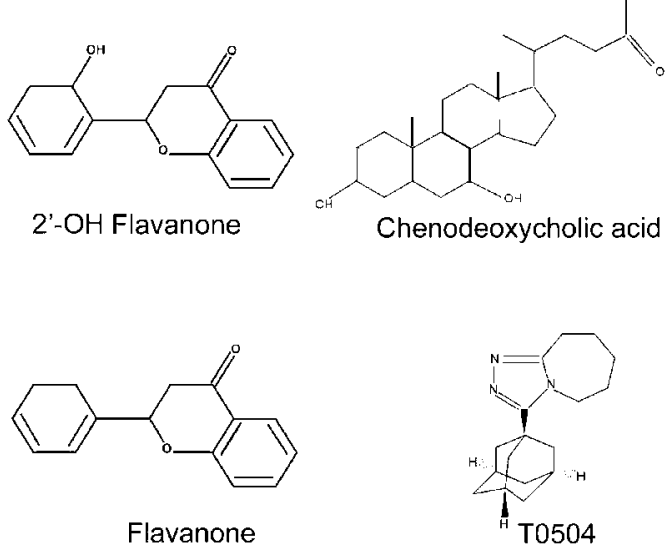
Table 2 Determination of the inhibitory effects of various compounds on the activities of 11 $\beta$-HSD1 from six species and of human $11 \beta \mathrm{HSD} 2$ in cell lysates. $11 \beta$-HSD activities were measured in cell lysates as described in Materials and methods. $I_{50}$ and $K_{\mathrm{i}}$ values are in $\mu \mathrm{M}$. Data represent mean \pm S.D. from at least four independent experiments

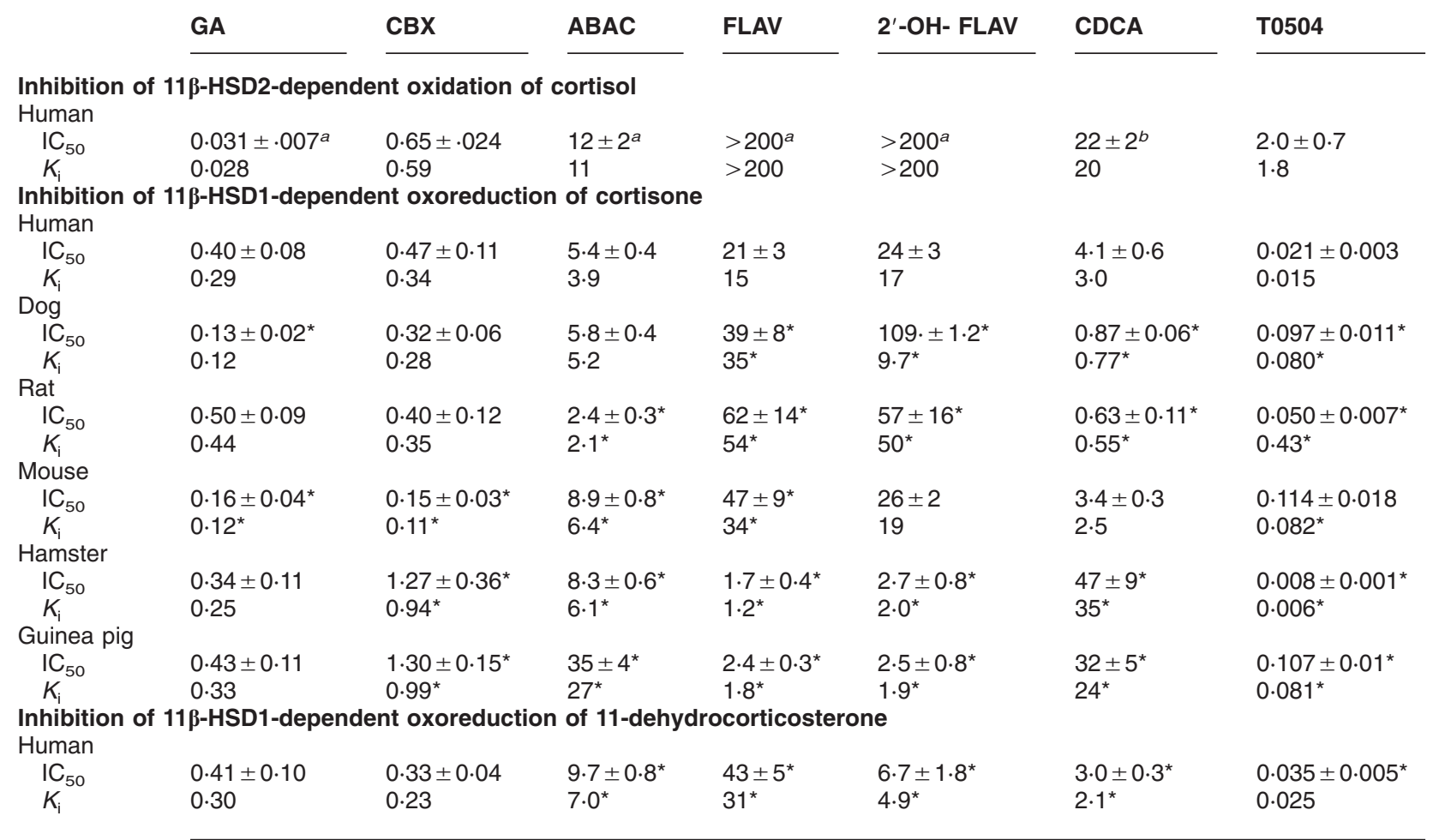

aValues were taken from (Schweizer et al. 2003); bvalue was taken from (Stauffer et al. 2002).

${ }^{*} \mathrm{p}<0.05$ compared with the cortisone reduction by human $11 \beta-H S D 1$.

lower, confirming the existence of huge species-specific differences of inhibitory compounds on $11 \beta$-HSD 1 activity. Next, we determined the dependence of the inhibitory effect from the substrate by measuring the inhibition of the oxoreduction of 11dehydrocorticosterone by human $11 \beta$-HSD 1 in the presence of various concentrations of the inhibitors. The compounds showed similar inhibitory effects when cortisone and 11-dehydrocorticosterone were used as substrates with rather modest differences. Importantly, flavanone and 2'-hydroxyflavanone comparably inhibited 11ß-HSD1-dependent activity with cortisone, but the latter compound was sixfold more potent with 11-dehydrocorticosterone, indicating that subtle differences in the molecular structures of both substrate and inhibitor are critical for the competition with stabilizing interactions in the hydrophobic binding pocket.

\section{Inhibitory effects in intact cells}

To assess the inhibitory potency of these compounds in intact cells, we transiently expressed FLAG-tagged $11 \beta$-HSD1 constructs from the six species in HEK-293 cells and measured the oxoreduction of cortisone in the presence of increasing concentrations of inhibitor. The most potent inhibitor was the uncharged compound $\mathrm{T} 0504\left(\mathrm{IC}_{50} 0 \cdot 157 \pm 0 \cdot 037 \mu \mathrm{M}\right)$. Both flavanone and 2 -hydroxyflavanone were more potent in intact cells than in cell lysates, with $\mathrm{IC}_{50}$ of $0.62 \pm 0.08 \mu \mathrm{M}$ and $3 \cdot 08 \pm 1 \cdot 49 \mu \mathrm{M}$ respectively, suggesting accumulation of these inhibitors. GA inhibited the oxoreduction of cortisone with an $\mathrm{IC}_{50} 1.64 \pm 0.69 \mu \mathrm{M}$, while $\mathrm{CBX}$ was less potent $\left(\mathrm{IC}_{50} \quad 10 \cdot 4 \pm 2 \cdot 0 \mu \mathrm{M}\right)$, indicating that the additional carboxy group hinders the entry of CBX into the cell. An unexpected inhibitory effect was observed for the bile acid CDCA. At concentrations up to $12 \mu \mathrm{M}$, a twofold activation of the 11ß-HSD1-dependent oxoreduction of cortisone was measured, followed by a typical inhibition curve with an $\mathrm{IC}_{50}$ of $230 \mu \mathrm{M}$. The inhibitory effect at these high concentrations was not due to detergent effect, since similar concentrations of

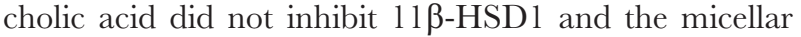
concentration is in the millimolar range.

We then assessed the species-specific effect in intact cells for the most potent inhibitor T0504 and the relatively weak inhibitor abietic acid on 11ß-HSD1-dependent oxoreduction of cortisone, to see whether the relative inhibitory potency observed in experiments with cell 
Table 3 Determination of the inhibitory effects of various compounds on $11 \beta$-HSD1 in intact cells. $11 \beta$-HSD1-dependent oxoreduction of cortisone was measured in intact, transiently transfected HEK-293 cells, as described in Materials and methods. $I C_{50}$ values are in $\mu \mathrm{M}$. Data represent mean \pm S.D. from four independent experiments.

\begin{tabular}{|c|c|c|}
\hline \multirow{3}{*}{ Species } & \multicolumn{2}{|l|}{$\mathrm{IC}_{50}[\mu \mathrm{M}]$} \\
\hline & $A B A C$ & T0504 \\
\hline & & \\
\hline Human & $15 \cdot 4 \pm 2 \cdot 6$ & $0.157 \pm 0.037$ \\
\hline Rat & $10 \cdot 9 \pm 1 \cdot 4^{*}$ & $0.274 \pm 0.054^{*}$ \\
\hline Mouse & $38 \cdot 6 \pm 10 \cdot 3^{*}$ & $1.66 \pm 0.42^{*}$ \\
\hline Hamster & n.d. & $0.101 \pm 0.014^{*}$ \\
\hline Guinea-pig & $103 \pm 15^{\star}$ & $0.805 \pm 0.138^{*}$ \\
\hline
\end{tabular}

n.d., not determined.

${ }^{*} p<0.05$ compared with human $11 \beta-H S D 1$.

lysates can be reproduced in intact cells. As shown in Table 3, the relative inhibitory strength of both compounds measured in intact cells followed that obtained in cell lysates. Hamster $11 \beta$-HSD1 was over 10-fold more sensitive to T0504 than the mouse enzyme, while rat $11 \beta$-HSD1 was inhibited at 10 -fold lower abietic acid concentrations than the guinea-pig enzyme.

\section{Discussion}

In the present study, we demonstrate significant species-specific variability of the enzymatic properties of $11 \beta$-HSD 1 for its substrates cortisone and 11dehydrocorticosterone as well as for its alternative substrate $7 \mathrm{KC}$. These differences have to be considered in trying to extrapolate results obtained from animal experiments to humans. Corticosterone is the major glucocorticoid in mice and rats, whereas cortisol is the major glucocorticoid in humans, thus limiting the use of these most commonly used rodents to study effects on glucocorticoid metabolism and action. Cortisol concentrations reach approximately $30 \%$ of the levels of corticosterone in hamsters (Ottenweller et al. 1985). In guinea pig, cortisol is the predominant glucocorticoid (Dalle \& Delost 1976); however, this animal is relatively resistant to glucocorticoids and shows a reduced affinity of cortisol to GR compared with humans (Keightley et al. 1998). Although some species use cortisone (human, dog, guinea pig) and others 11-dehydrocorticosterone (hamster, rat, mouse), we did not find a correlation between substrate use and affinity. In the assessment of the safety and efficacy of drugs, dogs are often used as a second animal model in addition to rats or mice. Our finding of significantly lower catalytic efficiency of canine than human $11 \beta$-HSD1, due to both reduced substrate affinity and lower maximal activity, is somewhat surprising and indicates potential limitations of the dog as a suitable model for the development of therapeutic $11 \beta$-HSD1 inhibitors.

We recently provided evidence that $11 \beta$-HSD 1 plays a role in the metabolism of $7 \mathrm{KC}$ (Schweizer et al. 2004). $7 \mathrm{KC}$ is the major dietary oxysterol formed during processing of cholesterol-rich food and is the major oxidation product of cholesterol found in human atherosclerotic plaques (Lyons \& Brown 1999). It is not clear whether the long-term treatment of humans with specific $11 \beta$-HSDl inhibitors may lead to an accumulation of $7 \mathrm{KC}$ and have a negative impact on health by promoting the development of atherosclerosis and dyslipidemia. To assess a potential risk from accumulation of $7 \mathrm{KC}$ upon long-term treatment with $11 \beta$-HSD 1 inhibitors, experiments in suitable animal models have to be performed. Because of their low 7-oxoreductase activities, guinea pigs and dogs are not suitable models for this purpose. In these animals, alternative pathways, such as 27-hydroxylase (Brown et al. 2000), may be responsible for the metabolism of $7 \mathrm{KC}$ and compensate for the lack of $11 \beta$-HSD1-dependent $7 \mathrm{KC}$ reduction. Our finding of very low 7-oxoreductase activity of guinea-pig 11 $\beta$-HSDl explains previous observations by Maeda et al. (2002), who reported background conversion of 7-oxycholesterols in guinea-pig liver microsomes. Due to the lack of stereospecificity of hamster $11 \beta$-HSD1, this animal model may also have its limitations, since the formation of $7 \alpha$-hydroxycholesterol, the first step in the elimination of cholesterol through the bile acid pathway, may lead to a more rapid removal of $7 \mathrm{KC}$. Rats and mice efficiently convert $7 \mathrm{KC}$ (Hult et al. 2004, Schweizer et al. 2004) and may be the most suitable animal models to study the interference of $11 \beta$-HSD 1 inhibitors with the detoxification of $7 \mathrm{KC}$.

Furthermore, our results show significant speciesspecific variability of the inhibitory effects of terpenoids, flavanoids, bile acids and other synthetic chemicals on $11 \beta$-HSD1 11-oxoreductase activity, further emphasizing that care should be taken when extrapolating results obtained from one animal model to other animals or to humans. The interpretation of data obtained from different species is most critical for inhibitors with a relatively low selectivity. CBX, an 11 1 -HSD inhibitor widely used in research, shows only a slight preference to inhibit human $11 \beta$-HSDl ( $\left.\mathrm{IC}_{50} 0.47 \mu \mathrm{M}\right)$ compared with human and mouse $11 \beta$-HSD2 $\left(\mathrm{IC}_{50} 0.65 \mu \mathrm{M}\right.$ and $0 \cdot 60 \mu \mathrm{M})$. However, CBX preferentially inhibits murine $11 \beta$-HSD2 $\left(\mathrm{IC}_{50} 0 \cdot 15 \mu \mathrm{M}\right)$. Thus, CBX may preferentially inhibit $11 \beta$-HSD1 in mouse disease models, whereas it is expected to cause more pronounced side effects in humans than in mice through inhibition of $11 \beta$-HSD2, which results in cortisol-dependent activation of the mineralocorticoid receptor and hypertension (Frey et al. 2004). 
CDCA has been used to treat cholesterol cholelithiasis in humans (Dyrszka et al. 1975, Okun et al. 1982), without significant toxicity. In contrast, lesions developed in rats treated with comparable concentrations of CDCA. There is controversy about the inhibitory effect of the bile acid CDCA on 11ß-HSDs. Diederich et al. (2000) suggested that CDCA acts as a selective $11 \beta$-HSD 1 inhibitor, with an $\mathrm{IC}_{50}$ of $2 \cdot 8 \mu \mathrm{M}$ obtained with human hepatic microsomes. Morris et al. (2004) reported inhibition of the dehydrogenase activity of $11 \beta$-HSD 1 with $\mathrm{IC}_{50}$ values of $0 \cdot 2-7 \mu \mathrm{M}$, but only $37-200 \mu \mathrm{M}$ for the oxoreductase activity in rat liver microsomes. They found weak inhibition of $11 \beta$-HSD2 from sheep kidney, with an $\mathrm{IC}_{50}$ of $70 \mu \mathrm{M}$. The use of different tissues and species makes it difficult to interpret these results and compare them with others. We have recently reported an $\mathrm{IC}_{50}$ value for CDCA of $22 \mu \mathrm{M}$ for the inhibition of human 11ß-HSD2, demonstrated CDCA-dependent, cortisol-induced activation of the mineralocorticoid receptor in intact cells, and provided evidence for bile acid-dependent inhibition of $11 \beta$ HSD2 in patients with cholestasis (Quattropani et al. 2001, Stauffer et al. 2002). The comparison of $K_{\mathrm{i}}$ values of human $11 \beta-\mathrm{HSD} 1$ and $11 \beta-\mathrm{HSD} 2$ revealed sevenfold selectivity of CDCA to inhibit $11 \beta$-HSD1. The comparison of the six species shows that CDCA is a potent inhibitor of rat and canine $11 \beta$-HSD 1 , with over 50 -fold higher potency than hamster and guinea-pig $11 \beta$-HSD1. Our measurements with intact HEK-293 cells transiently expressing human $11 \beta$-HSD1 emphasize that the relative inhibition of $11 \beta$-HSD1 and $11 \beta$-HSD2 seen in cell lysates cannot be directly extrapolated to intact cells. In intact HEK-293 cells, CDCA showed a biphasic effect with activation at low concentrations followed by inhibition at high concentrations. Although CDCA was able to inhibit $11 \beta$ HSD2, which is oriented into the cytoplasm, and mediates cortisol-dependent activation of mineralocorticoid receptor (Stauffer et al. 2002), it was unable to block the 11 1 -HSD1-dependent conversion of cortisone in the endoplasmic reticulum lumen and prevent subsequent GR activation (not shown). The huge variability found with different species and assay systems may explain some of the controversial findings, and it further emphasizes the necessity of the appropriate use of suitable cell systems and animal models.

In contrast to CDCA and abietic acid, the two selective $11 \beta$-HSD1 inhibitors flavanone and 2'-hydroxyflavanone (Schweizer et al. 2004) most efficiently inhibited hamster and guinea-pig $11 \beta$-HSD 1 , but were very weak inhibitors of the rat and mouse enzymes, suggesting differences in the binding of flavanoids, compared with bile acids and diterpenoids, to the hydrophobic pocket. The subtle difference of the presence of a single hydroxyl group enhanced the potency of 2'-hydroxyflavanone to inhibit the oxoreduction of cortisone by twofold in mouse and fourfold in canine $11 \beta$-HSD1. Furthermore, the distinct inhibition of the oxoreduction of the two substrates cortisone and 11-dehydrocorticosterone by flavanone and 2'-hydroxyflavanone suggests that such compounds may exert different physiologic effects, depending on whether cortisone- or 11dehydrocorticosterone-based species are used in the assessment of inhibitory effects. The pharmaceutical compound T0504 is a highly potent inhibitor of human $11 \beta$-HSD 1 and shows 100-fold selectivity toward human $11 \beta$-HSD2. The significant species effects were also observed for this compound, with the lowest $K_{\mathrm{i}}$ value for $11 \beta$-HSD 1 from hamster, a threefold higher $K_{\mathrm{i}}$ for human 11 $\beta$-HSD1 and over 10-fold higher $K_{\mathrm{i}}$ values for mouse and $\operatorname{dog} 11 \beta$-HSD1. These species-specific effects may become relevant in investigating the inhibition of $11 \beta$-HSD1 in vivo. If human and mouse $11 \beta$-HSD2 were similarly inhibited by T0504 (remains to be determined), the selectivity to inhibit $11 \beta$-HSD 1 would be limited to 10 -fold in mouse and side effects would be more likely to occur.

The experimental data suggest that the chemicals analyzed in the present study competitively inhibit $11 \beta$-HSD1. Figure $5 \mathrm{~A}$ shows a pharmacophore model based on the solved crystal structure of $11 \beta$-HSD1 (1XU9) with cortisone in the binding pocket. CBX, GA and CDCA fitted well into the 1XU9 model consisting of five hydrogen bond acceptor features and three hydrophobic features, and all three inhibitors seem to occupy competitively the cortisone-binding pocket (Fig. 5B). Abietic acid, flavanone, 2'-hydroxyflavanone and T0504 are comparably small compounds and do not possess enough chemical features to fit into the pharmacophore; therefore, they were fitted into the common feature model consisting of three hydrophobic features and one hydrogen bond acceptor feature. The common features represent hydrophobic regions in close vicinity to $\mathrm{Leu}^{217}(\mathrm{~A}), \mathrm{Ala}^{172}(\mathrm{~B})$ and $\mathrm{Leu}^{126} / \mathrm{Ala}^{226}(\mathrm{C})$ as well as a hydrogen bond to Tyr ${ }^{177}$. All four inhibitors fitted into the common feature model of $11 \beta$-HSD1, indicating that they are able to occupy sites of the ligand-binding domain important for enzyme inhibition (Fig. 5C). The modeling approach showed that the presented inhibitors are all able to fit into the ligand-binding domain of $11 \beta$-HSD 1 ; however, as this pharmacophore describes the interaction sites between a ligand and the protein qualitatively, no quantitative information about binding strength can be gained from such a model. From the common feature model, it can be concluded that three hydrophobic sites and one hydrogen bond play essential roles in enzyme inhibition. To gain further insight into inhibition mechanisms of $11 \beta$-HSD1, expanded molecular modeling studies will be required.

In conclusion, our results revealed significant speciesspecific differences in the inhibition of $11 \beta$-HSD 1 by 

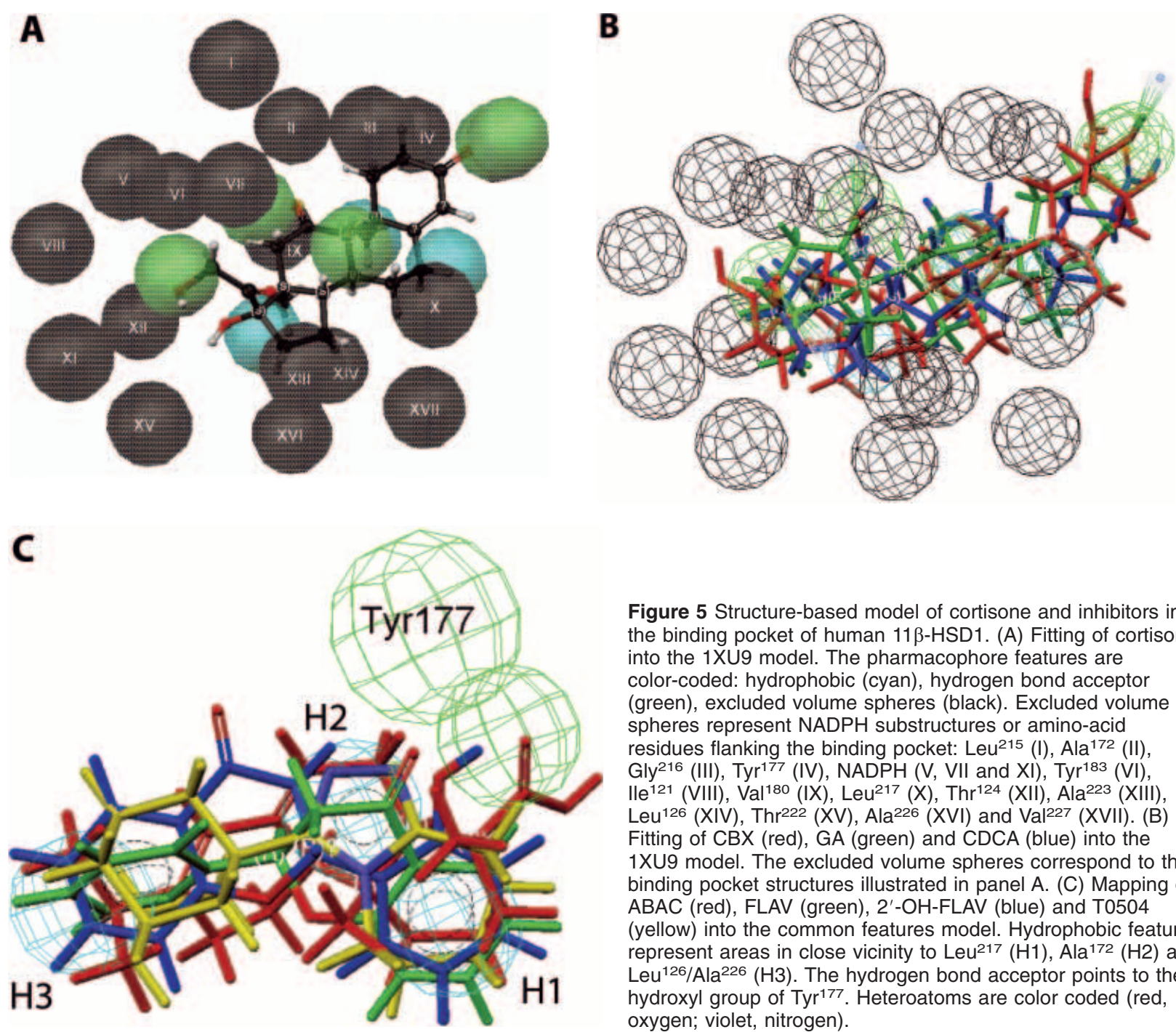

Figure 5 Structure-based model of cortisone and inhibitors in the binding pocket of human $11 \beta-H S D 1$. (A) Fitting of cortisone into the 1XU9 model. The pharmacophore features are color-coded: hydrophobic (cyan), hydrogen bond acceptor (green), excluded volume spheres (black). Excluded volume spheres represent NADPH substructures or amino-acid residues flanking the binding pocket: Leu ${ }^{215}(\mathrm{I}), \mathrm{Ala}^{172}$ (II), Gly $^{216}$ (III), Tyr ${ }^{177}$ (IV), NADPH (V, VII and XI), Tyr ${ }^{183}$ (VI), $\mathrm{Ile}^{121}$ (VIII), Val ${ }^{180}(\mathrm{IX}), \mathrm{Leu}^{217}(\mathrm{X}), \mathrm{Thr}^{124}$ (XII), Ala223 (XIII), Leu $^{126}(\mathrm{XIV}), \mathrm{Thr}^{222}(\mathrm{XV}), \mathrm{Ala}^{226}(\mathrm{XVI})$ and Val'227 (XVII). (B) Fitting of CBX (red), GA (green) and CDCA (blue) into the 1XU9 model. The excluded volume spheres correspond to the binding pocket structures illustrated in panel A. (C) Mapping of ABAC (red), FLAV (green), 2'-OH-FLAV (blue) and T0504 (yellow) into the common features model. Hydrophobic features represent areas in close vicinity to Leu ${ }^{217}(\mathrm{H} 1)$, Ala ${ }^{172}(\mathrm{H} 2)$ and $\mathrm{Leu}^{126} / \mathrm{Ala}^{226}(\mathrm{H} 3)$. The hydrogen bond acceptor points to the hydroxyl group of Tyr ${ }^{177}$. Heteroatoms are color coded (red, oxygen; violet, nitrogen).

several chemicals from different classes that all occupy the hydrophobic binding pocket. We suggest that after in vitro testing and selection of potential $11 \beta$-HSD 1 inhibitors for therapeutic applications, the effect of such inhibitors on the recombinant enzyme from the corresponding species be determined before initiating extensive in vivo tests.

\section{Acknowledgements}

We thank Drs Roger Clerc and Kurt Amrein of Hoffmann LaRoche, Basel, for providing dog liver cDNA and for helpful discussion and support. We thank Heidi Jamin for excellent technical support and Dr. Bernhard Dick for advice with GC/MS analyses. A O is a Cloëtta Research Fellow. This work was supported by grants from the Swiss National Science Foundation no. 3100A0-100060 and National Research Program No. 50 'Endocrine Disruptors' no. 4050-066575. T L and D S were supported by Inte:Ligand $\mathrm{GmbH}$. The authors declare that there is no conflict of interest that would prejudice the impartiality of this scientific work.

\section{References}

Agarwal AK, Monder C, Eckstein B \& White PC 1989 Cloning and expression of rat cDNA encoding corticosteroid 11 betadehydrogenase. Fournal of Biological Chemistry 264 18939-18943.

Alberts P, Nilsson C, Selen G, Engblom LO, Edling NH, Norling S, Klingstrom G, Larsson C, Forsgren M, Ashkzari M et al. 2003 Selective inhibition of 11 beta-hydroxysteroid dehydrogenase type 1 improves hepatic insulin sensitivity in hyperglycemic mice strains. Endocrinology 144 4755-4762. 
Atanasov AG, Tam S, Rocken JM, Baker ME \& Odermatt A 2003 Inhibition of 11 beta-hydroxysteroid dehydrogenase type 2 by dithiocarbamates. Biochemical and Biophysical Research Communications 308 257-262.

Atanasov AG, Nashev LG, Schweizer RA, Frick C \& Odermatt A 2004 Hexose-6-phosphate dehydrogenase determines the reaction direction of 11 beta-hydroxysteroid dehydrogenase type 1 as an oxoreductase. FEBS Letters 571 129-133.

Barf T, Vallgarda J, Emond R, Haggstrom C, Kurz G, Nygren A, Larwood V, Mosialou E, Axelsson K, Olsson R et al. 2002 Arylsulfonamidothiazoles as a new class of potential antidiabetic drugs. Discovery of potent and selective inhibitors of the 11 beta-hydroxysteroid dehydrogenase type 1. Fournal of Medicinal Chemistry 45 3813-3815.

Barnes PJ 1998 Anti-inflammatory actions of glucocorticoids: molecular mechanisms. Clinical Science (London) 94 557-572.

Berman HM, Westbrook J, Feng Z, Gilliland G, Bhat TN, Weissig H, Shindyalov IN \& Bourne PE 2000 The Protein Data Bank. Nucleic Acids Research 28 235-242.

Brown AJ, Watts GF, Burnett JR, Dean RT \& Jessup W 2000 Sterol 27-hydroxylase acts on 7-ketocholesterol in human atherosclerotic lesions and macrophages in culture. Fournal of Biological Chemistry 275 27627-27633.

Cheng Y \& Prusoff WH 1973 Relationship between the inhibition constant $\left(K_{\mathrm{i}}\right)$ and the concentration of inhibitor which causes 50 per cent inhibition $\left(\mathrm{I}_{50}\right)$ of an enzymatic reaction. Biochemical Pharmacology 22 3099-3108.

Chrousos GP 2004 Is 11 beta-hydroxysteroid dehydrogenase type 1 a good therapeutic target for blockade of glucocorticoid actions? PNAS $1016329-6330$.

Dalle M \& Delost P 1976 Plasma and adrenal cortisol concentrations in foetal, newborn and mother guinea-pigs during the perinatal period. Fournal of Endocrinology $\mathbf{7 0}$ 207-214.

De Bosscher K, Vanden Berghe W \& Haegeman G 2003 The interplay between the glucocorticoid receptor and nuclear factor-kappaB or activator protein-1: molecular mechanisms for gene repression. Endocrine Reviews 24 488-522.

Diederich S, Grossmann C, Hanke B, Quinkler M, Herrmann M, Bahr V \& Oelkers W 2000 In the search for specific inhibitors of human 11 beta-hydroxysteroid-dehydrogenases (11 beta-HSDs), chenodeoxycholic acid selectively inhibits 11 beta-HSD-I. European Fournal of Endocrinology 142 200-207.

Dyrszka H, Chen T, Salen G \& Mosbach EH 1975 Toxicity of chenodeoxycholic acid in the rhesus monkey. Gastroenterology 69 333-337.

Frey FJ, Odermatt A \& Frey BM 2004 Glucocorticoid-mediated mineralocorticoid receptor activation and hypertension. Current Opinion in Nephrology and Hypertension 13 451-458.

Hult M, Elleby B, Shafqat N, Svensson S, Rane A, Jornvall H, Abrahmsen L \& Oppermann U 2004 Human and rodent type 1 11 beta-hydroxysteroid dehydrogenases are 7 betahydroxycholesterol dehydrogenases involved in oxysterol metabolism. Cellular and Molecular Life Sciences 61 992-999.

Kannisto K, Pietilainen KH, Ehrenborg E, Rissanen A, Kaprio J, Hamsten A \& Yki-Jarvinen H 2004 Overexpression of $11 \beta$ hydroxysteroid dehydrogenase- 1 in adipose tissue Is associated with acquired obesity and features of insulin resistance: studies in young adult monozygotic twins. Fournal of Clinical Endocrinology and Metabolism $894414-4421$.

Keightley MC, Curtis AJ, Chu S \& Fuller PJ 1998 Structural determinants of cortisol resistance in the guinea pig glucocorticoid receptor. Endocrinology 139 2479-2485.

Kotelevtsev Y, Holmes MC, Burchell A, Houston PM, Schmoll D, Jamieson P, Best R, Brown R, Edwards CR, Seckl JR et al. 1997 11 beta-hydroxysteroid dehydrogenase type 1 knockout mice show attenuated glucocorticoid-inducible responses and resist hyperglycemia on obesity or stress. PNAS 94 14924-14929.
Lindsay RS, Wake DJ, Nair S, Bunt J, Livingstone DE, Permana PA, Tataranni PA \& Walker BR 2003 Subcutaneous adipose 11 beta-hydroxysteroid dehydrogenase type 1 activity and messenger ribonucleic acid levels are associated with adiposity and insulinemia in Pima Indians and Caucasians. Fournal of Clinical Endocrinology and Metabolism 88 2738-2744.

Lyons MA \& Brown AJ 1999 7-Ketocholesterol. International fournal of Biochemistry and Cell Biology 31 369-375.

Maeda Y, Nagatomo H, Uchiyama F, Nagatomo J, Yamada M, Shiotsuki H, Ohta Y, Sato S, Kai MH, Kondo KH et al. 2002 A comparative study of the conversion of 7-hydroxycholesterol in rabbit, guinea pig, rat, hamster, and chicken. Steroids 67 703-708.

Masuzaki H \& Flier JS 2003 Tissue-specific glucocorticoid reactivating enzyme, 11 betahydroxysteroid dehydrogenase type 1 (11 beta-HSD1) - a promising drug target for the treatment of metabolic syndrome. Current Drug Targets. Immune, Endocrine and Metabolic Disorders 3 255-262.

Masuzaki H, Paterson J, Shinyama H, Morton NM, Mullins JJ, Seckl JR \& Flier JS 2001 A transgenic model of visceral obesity and the metabolic syndrome. Science 294 2166-2170.

Masuzaki H, Yamamoto H, Kenyon CJ, Elmquist JK, Morton NM, Paterson JM, Shinyama H, Sharp MG, Fleming S, Mullins JJ et al. 2003 Transgenic amplification of glucocorticoid action in adipose tissue causes high blood pressure in mice. Foumal of Clinical Investigation 112 83-90.

Morris DJ, Souness GW, Latif SA, Hardy MP \& Brem AS 2004 Effect of chenodeoxycholic acid on 11 beta-hydroxysteroid dehydrogenase in various target tissues. Metabolism 53 811-816.

Morton NM, Paterson JM, Masuzaki H, Holmes MC, Staels B, Fievet C, Walker BR, Flier JS, Mullins JJ \& Seckl JR 2004 Novel adipose tissue-mediated resistance to diet-induced visceral obesity in 11 beta-hydroxysteroid dehydrogenase type 1-deficient mice. Diabetes 53 931-938.

Odermatt A, Arnold P, Stauffer A, Frey BM \& Frey FJ 1999 The $\mathrm{N}$-terminal anchor sequences of 11 beta-hydroxysteroid dehydrogenases determine their orientation in the endoplasmic reticulum membrane. Fournal of Biological Chemistry 274 28762-28770.

Okun R, Goldstein LI, Van Gelder GA, Goldenthal EI, Wazeter FX \& Giel RG 1982 National Cooperative Gallstone Study: nonprimate toxicology of chenodeoxycholic acid. Fournal of Toxicology and Environmental Health 9 727-741.

Oppermann UC, Netter KJ \& Maser E 1995 Cloning and primary structure of murine 11 betahydroxysteroid dehydrogenase/ microsomal carbonyl reductase. European Fournal of Biochemistry 227 202-208.

Ottenweller JE, Tapp WN, Burke JM \& Natelson BH 1985 Plasma cortisol and corticosterone concentrations in the golden hamster (Mesocricetus auratus). Life Sciences 37 1551-1558.

Paterson JM, Morton NM, Fievet C, Kenyon CJ, Holmes MC, Staels B, Seckl JR \& Mullins JJ 2004 Metabolic syndrome without obesity: hepatic overexpression of 11 beta-hydroxysteroid dehydrogenase type 1 in transgenic mice. PNAS 101 7088-7093.

Paulmyer-Lacroix O, Boullu S, Oliver G, Alessi MC \& Grino M 2002 Expression of the mRNA coding for 11 beta-hydroxysteroid dehydrogenase type 1 in adipose tissue from obese patients: an in situ hybridization study. Fournal of Clinical Endocrinology and Metabolism 87 2701-2705.

Pu X \& Yang K 2000 Guinea pig 11 beta-hydroxysteroid dehydrogenase type 1: primary structure and catalytic properties. Steroids $\mathbf{6 5}$ 148-156.

Quattropani C, Vogt B, Odermatt A, Dick B, Frey BM \& Frey FJ 2001 Reduced activity of 11 beta-hydroxysteroid dehydrogenase in patients with cholestasis. Fournal of Clinical Investigation $\mathbf{1 0 8}$ 1299-1305.

Rajan V, Chapman KE, Lyons V, Jamieson P, Mullins JJ, Edwards CR \& Seckl JR 1995 Cloning, sequencing and tissue-distribution of mouse 11 beta-hydroxysteroid dehydrogenase-1 cDNA. Fournal of Steroid Biochemistry and Molecular Biology 52 141-147. 
Rask E, Walker BR, Soderberg S, Livingstone DE, Eliasson M, Johnson O, Andrew R \& Olsson T 2002 Tissue-specific changes in peripheral cortisol metabolism in obese women: increased adipose 11 beta-hydroxysteroid dehydrogenase type 1 activity. Fournal of Clinical Endocrinology and Metabolism 87 3330-3336.

Rauz S, Cheung CM, Wood PJ, Coca-Prados M, Walker EA, Murray PI \& Stewart PM 2003 Inhibition of 11 beta-hydroxysteroid dehydrogenase type 1 lowers intraocular pressure in patients with ocular hypertension. Quarterly Journal of Medicine 96 481-490.

Sandeep TC \& Walker BR 2001 Pathophysiology of modulation of local glucocorticoid levels by 11 beta-hydroxysteroid dehydrogenases. Trends in Endocrinology and Metabolism 12 446-453.

Sandeep TC, Yau JL, MacLullich AM, Noble J, Deary IJ, Walker BR \& Seckl JR 200411 beta-hydroxysteroid dehydrogenase inhibition improves cognitive function in healthy elderly men and type 2 diabetics. PNAS 10167346739.

Schweizer RA, Atanasov AG, Frey BM \& Odermatt A 2003 A rapid screening assay for inhibitors of 11 beta-hydroxysteroid dehydrogenases (11 beta-HSD): flavanone selectively inhibits 11 beta-HSD1 reductase activity. Molecular and Cellular Endocrinology $21241-49$

Schweizer RA, Zurcher M, Balazs Z, Dick B \& Odermatt A 2004 Rapid hepatic metabolism of 7-ketocholesterol by $11 \beta$-hydroxysteroid dehydrogenase type 1: species-specific differences between the rat, human, and hamster enzyme. Fournal of Biological Chemistry 279 18415-18424.

Stauffer AT, Rochat MK, Dick B, Frey FJ \& Odermatt A 2002 Chenodeoxycholic acid and deoxycholic acid inhibit 11 beta-hydroxysteroid dehydrogenase type 2 and cause cortisol-induced transcriptional activation of the mineralocorticoid receptor. Fournal of Biological Chemistry 277 26286-26292.

Stewart PM \& Krozowski ZS 199911 beta-hydroxysteroid dehydrogenase. Vitamins and Hormones 57 249-324.

Tannin GM, Agarwal AK, Monder C, New MI \& White PC 1991 The human gene for 11 beta-hydroxysteroid dehydrogenase. Structure, tissue distribution, and chromosomal localization. Fournal of Biological Chemistry 266 16653-16658.

Valsamakis G, Anwar A, Tomlinson JW, Shackleton CH, McTernan PG, Chetty R, Wood PJ, Banerjee AK, Holder G, Barnett AH et al. 200411 beta-hydroxysteroid dehydrogenase type 1 activity in lean and obese males with type 2 diabetes mellitus. Fournal of Clinical Endocrinology and Metabolism 89 4755-4761.

Wolber G \& Langer T 2005 LigandScout: 3-D pharmacophores derived from protein-bound ligands and their use as virtual screening filters. Fournal of Chemical Information and Modeling $\mathbf{4 5}$ $160-169$.

Received 7 April 2005

Accepted 22 April 2005

Made available online as an Accepted Preprint 12 May 2005 